\title{
A neonate with acute kidney injury
}

\section{Farzana Ahmed, Sanjoy Kumar Dey, Md. Abdul Mannan and Mohammod Shahidullah}

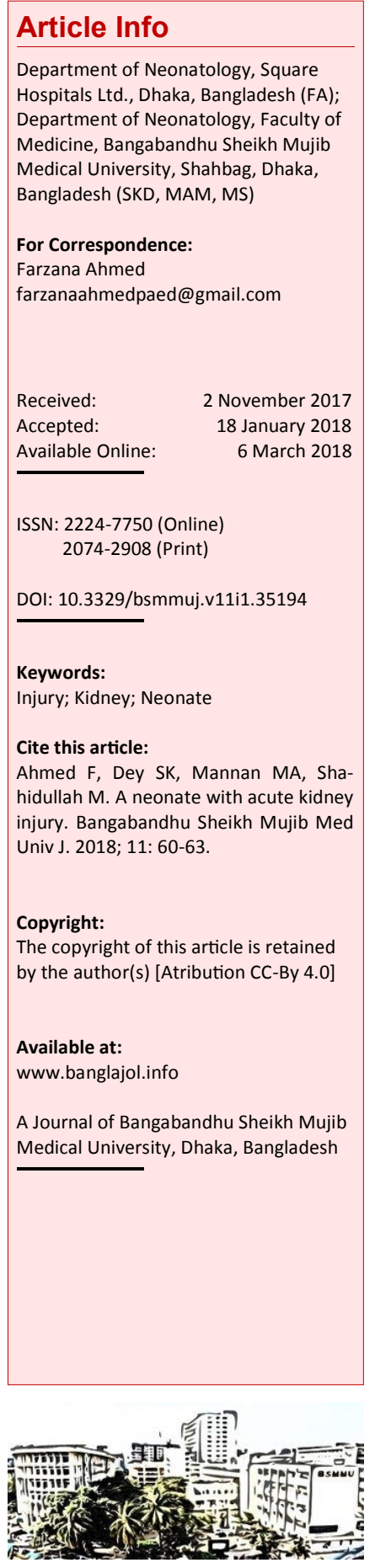

\section{Case Presentation}

Dr. Rezaul Hayat: An outborn, 2 hours old male newborn was admitted at the neonatal intensive care unit due to delayed cry after birth and respiratory distress soon after birth. The baby was born at 39 weeks of gestation at an another hospital to a 30 year old primi mother by lower uterine caesarian section due to the obstructed labor. Although the mother was not in regular antenatal checkup. Her pregnancy period was uncomplicated.

The baby was limp and blue immediately after birth and was managed accordingly by the attending physician and was referred to the Neonatal Intensive Care Unit of Bangabandhu Sheikh Mujib Medical University for better management. APGAR score was not documented. On initial examination on arrival, the baby was lethargic, euglycemic, vitally stable except tachypnea but maintaining saturation with oxygen inhalation at the rate of 2 liter per min. Initial septic screening was positive. So, the first line antibiotics- injection ampicillin and gentamicin were started. Gradually his respiratory distress increased. So, the baby was put on mechanical ventilator at 16 hours of age. Antibiotics were changed due to poor response to medications and injection meropenum and amikacin started after renal dose adjustment and was continued for total 14 days.

From second day onward, the baby developed edema and unusual weight gain. The baby was normotensive with adequate urine output. There was no sign of heart failure. Investigation report revealed high level of serum creatinine which further increased on the following day despite of renal dose adjustment of medication (Figure 1).

The serum calcium level was low which was corrected by the calcium supplementation (Table I). The serum sodium level was also low despite of fluid restriction. So, further total fluid restricted to insensible loss $(30 \mathrm{~mL} / \mathrm{kg})$ plus replacement of equal amount of the urine output. Gradually, his condition was improved and was weaned from the mechanical ventilator on day 4 of life, edema subsided, serum creatinine level decreased, hyponatremia corrected. So, the baby was discharged from hospital on $18^{\text {th }}$ days of age.

\section{Provisional Diagnosis}

Term with appropriate gestational age with perinatal asphyxia with neonatal sepsis with acute kidney injury.

\section{Differential Diagnosis}

Dr. Farzana Ahmed: The newborn baby presented with acute kidney injury. The cause of acute kidney injury might be due to perinatal asphyxia or neonatal sepsis. The prerenal, postrenal causes and congenital anomaly in the urinary tract might also cause the acute kidney injury in this age group which also should be excluded.

\section{Acute kidney injury due to perinatal asphyxia}

Acute kidney injury can occur in 50-60\% neonates with severe perinatal asphyxia. APGAR score was less than 4 and the base deficit $>15$ $\mathrm{mEq} / \mathrm{L}$ at one hour after birth are consider as independent risk factors for development of acute kidney injury in newborn.1,2 In perinatal asphyxia, the redistribution of blood flow occurs to provide the optimal blood circulation to the brain, heart and adrenal glands, circulation decrease in skin and splanchnic vessels. This mechanism is called "Diving Reflex". By this mechanism, acute tubular necrosis may occur which leads to acute kidney injury in newborn. $.2-4$

\section{Acute kidney injury due to neonatal sepsis}

Sepsis contributes up to $78 \%$ cases of the acute kidney injury in newborn. 5,6 Preterm low birth weight newborns with sepsis are vulnerable to develop acute kidney injury than their term counterpart.6, 7 Previously, it was assumed that hypotension associated with systemic inflammatory responses cause the renal failure. Now-a-days it had been observed that renal failure might occur despite of normal blood pressure suggesting direct kidney injury in sepsis by effects on renal microvasculature. $\frac{6-9}{-9}$ 


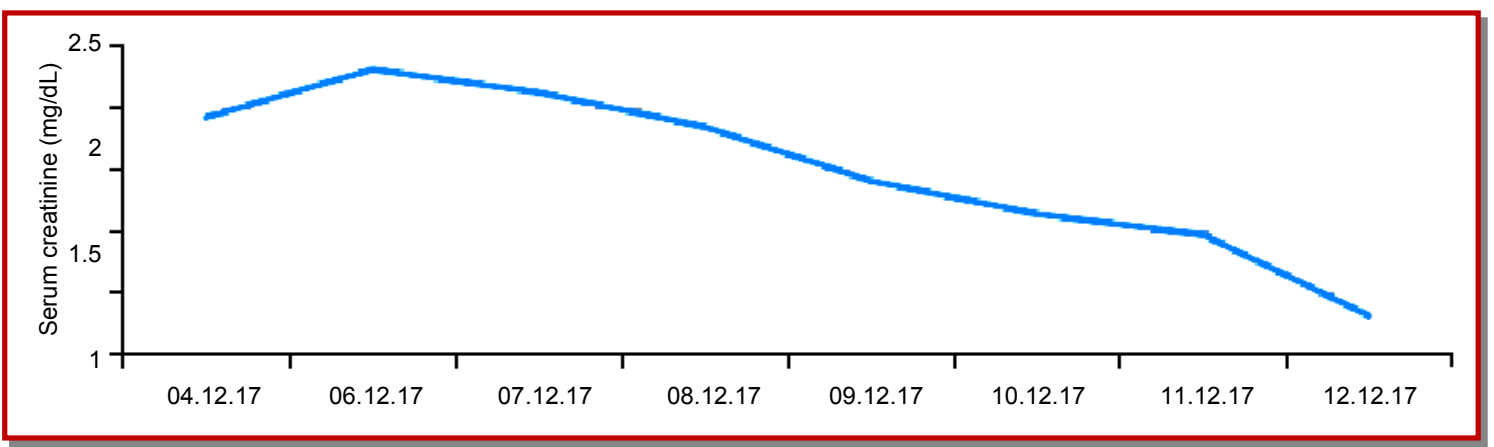

Figure 1: Serum creatinine level (mg/dL)

\begin{tabular}{|c|c|c|}
\hline \multicolumn{3}{|c|}{ Table I } \\
\hline \multicolumn{3}{|c|}{ Investigation profile } \\
\hline Investigation & $\begin{array}{l}\text { Reference range } \\
\text { (newborn) }\end{array}$ & Patient's value \\
\hline Hemoglobin $(\mathrm{g} / \mathrm{dL})$ & $15-20$ & 19.3 \\
\hline White cell count $\left(\times 10^{9} / \mathrm{L}\right)$ & $5-25$ & 35 \\
\hline $\begin{array}{l}\text { Immature to total neutro- } \\
\text { phil ratio }\end{array}$ & $<0.2$ & 0.25 \\
\hline C-Reactive protein (mg/dL) & $<6$ & 84.4 \\
\hline $\begin{array}{l}\text { Peripheral blood film (White } \\
\text { blood cell) }\end{array}$ & $\begin{array}{l}\text { Absence of band } \\
\text { form, toxic gran- } \\
\text { ules }\end{array}$ & $\begin{array}{l}\text { Mature with normal in } \\
\text { count and distribution, } \\
\text { some band from and toxic } \\
\text { granules seen }\end{array}$ \\
\hline \multicolumn{3}{|l|}{ Serum electrolyte level } \\
\hline Sodium (mmol/L) & $135-145$ & 128 \\
\hline Potassium (mmol/L) & $3.5-5.5$ & 5.2 \\
\hline Chloride (mmol/L) & $95-107$ & 93 \\
\hline Calcium (mg/dL) & $7-10$ & 6.6 \\
\hline Magnesium (mg/dL) & $1.6-2.4$ & 1.7 \\
\hline Total $\mathrm{CO}_{2}(\mathrm{mmol} / \mathrm{L})$ & $24-30$ & 22.4 \\
\hline
\end{tabular}

\begin{tabular}{|c|c|c|}
\hline \multicolumn{3}{|c|}{ Table II } \\
\hline \multicolumn{3}{|c|}{ Difference between prerenal and intrinsic renal failure } \\
\hline Test & $\begin{array}{l}\text { Prerenal acute renal } \\
\text { failure }\end{array}$ & Intrinsic renal failure \\
\hline Urine urea & High & low \\
\hline Urine creatinine & High & Low \\
\hline $\begin{array}{l}\text { Urine osmolality } \\
(\mathrm{mOsmol} / \mathrm{Kg})\end{array}$ & High $(>500)$ & Low $(>300)$ \\
\hline Specific gravity & High $(>1.025)$ & Low $(>1.010)$ \\
\hline Urine sodium (mmol/L) & Low $(<10)$ & $\operatorname{High}(>20)$ \\
\hline Urine/plasma urea & High $(>10)$ & Low \\
\hline Urine/plasma creatinine & High (40) & Low \\
\hline Urine/plasma osmolality & High $(>2)$ & Low $(0.1)$ \\
\hline $\begin{array}{l}\text { FENa (Fractionated excre- } \\
\text { ation of sodium) }\end{array}$ & Low $(<1 \%)$ & High $(>3 \%)$ \\
\hline Renal failure index & Low $(<1)$ & High $(>4)$ \\
\hline
\end{tabular}

\section{Dr. Hayat's Diagnosis}

Term with appropriate gestational age with perinatal asphyxia with neonatal sepsis with acute kidney injury.

\section{Discussion}

Dr. Ahmed: With proper antenatal and postnatal care, accelerated change in the child survival is observed over the last decade but neonatal mortality rate is still a burning issue. Global neonatal mortality rate fell from 37 deaths per 1,000 live births in 1990 to 19 per 1,000 in 2016.10 In Bangladesh, neonatal mortality rate is 20 per 1,000 live births. 11 Acute kidney injury is one of the common preventable and treatable pathological conditions in newborn which occurs in 1-24\% newborn admitted in the neonatal intensive care unit.12 The incidence of acute kidney injury in Bangladesh is $14.1 \%$ in newborn admitted at the neonatal intensive care unit, among them, mortality rate is $17.2 \% . \underline{12,13}$

The causes of neonatal acute kidney injury are multiple and the three classic categories into which they are divided are: prerenal, renal (intrinsic or organic) and postrenal. Prerenal acute kidney injury (also known as vasomotor nephropathy) is the most common form in the neonatal period, with an incidence of $85 \%$ of cases of acute kidney injury. 14 In Bangladesh, most predominant cause of acute kidney injury in newborn is the perinatal asphyxia followed by septicemia. $\frac{15-19}{}$

Dr. Iffat Rahman: Can prerenal causes of acute kidney injury can cause intrinsic renal failure? If yes then how?

Dr. Ahmed: Although prerenal form of acute kidney injury, post-glomerular blood flow remains sufficient but following a serious and prolonged ischemia, a series of anatomic alterations might takes place which may cause acute tubular necrosis. $\underline{20-23}$

Dr. Rumman Idris: How prerenal causes can be distinguished from the intrinsic renal causes of acute kidney injury?

Dr. Ahmed: By the following ways, prerenal causes 
can be distinguished from postrenal causes (Table II)..$\underline{24-26}$

Dr. Sumon Sorkar: Is there any rule of fluid challenge test in newborn?

Dr. Ahmed: Fluid challenge test can differentiate prerenal from the intrinsic renal causes of acute renal failures but the fluid should be given slowly in newborn specially in preterm babies. $\underline{.27-30}$

Dr. Bipin Karki: Is there any rule of ionotopic agents test for acute kidney injury in newborn?

Dr. Ahmed: Although it is augmented that low dose dopamine $(0.5-2.0 \mu \mathrm{g} / \mathrm{kg} / \mathrm{min})$ renal vasodilatation and increase salt water excretion but no study yet done on this topic in neonate. Furthermore, a receptors are relatively high in preterm newborn, so, even low dose of dopamine might put them in risk of systemic hypertension. $\underline{24,31-33}$

Dr. Sorbori Saha: What is the outcome of newborn suffered from acute kidney injury?

Dr. Ahmed: Both immediate and long term outcome in babies with acute kidney injury are not good. In many long term prospective studies proved that even those neonate who had achieved full recovery initially, later developed chronic kidney disease. So, to combat this fatal disease, recent KDIGO practice guidelines recommend that all patients who experience acute kidney injury should be evaluated after 3 months for new onset or worsening of chronic kidney disease. $\underline{.34-37}$

\section{Final Diagnosis}

Term with appropriate gestational age with perinatal asphyxia with neonatal sepsis with acute kidney injury.

\section{References}

1. Srivastava RN, Bagga A. Acute kidney injury. In: Paediatric nephrology. $5^{\text {th }}$ ed. New Delhi, Jaypee Brother Medical Published, 2011, pp 235-36.

2. Sarkar S, Askenazi DJ, Jordan BK, Bhagat I, Bapuraj JR, Dechert RE, Selewski DT Relationship between acute kidney injury and brain MRI findings in asphyxiated newborns after therapeutic hypothermia. Pediatric Res. 2014;75: 431-35.

3. Gomella TL, Cunningham MD, Eyal FG. Neonatology. $7^{\text {th }}$ ed. New York, McGraw Hill Education, 2013, pp 830-33.

4. Ricci Z, Ronco C. Neonatal RIFLE. Nephrol Dial Transplant. 2013; 28: 2211-14.

5. Jetton JG, Askenazi DJ. Update on acute kidney injury in the neonate. Curr Opin Pediatr. 2012; 24: 191-96.

6. Selewski DT, Charlton JR, Jetton JG, Guillet R, Mhanna MJ, Askenazi DJ, Kent AL. Neonatal acute kidney injury. Pediatrics 2015;136: e463-73.

7. Carmody JB, Swanson JR, Rhone ET, Charlton JR. Recognition and Reporting of AKI in Very Low Birth Weight Infants. Clin J Am Soc Nephrol. 2014; 9: 1-8.

8. Cataldi L, Leone R, Moretti U, De Mitri B, Fanos V, Ruggeri L, Sabatino G, Torcasio F, Zanardo V, Attardo G, Riccobene F, Martano C, Benini D, Cuzzolin L. Potential risk factors for the development of acute renal failure in preterm newborn infants: A case-control study. Arch Dis Child Fetal Neonatal Ed. 2005; 90: 514-19.

9. Koralkar R, Ambalavanan $\mathrm{N}$, Levitan EB, McGwin G, Goldstein S, Askenazi D. Acute kidney injury reduces survival in very low birth weight infants. Pediatr Res. 2011; 69: 354-58.

10. United Nations Inter-agency Group for Child Mortality Estimation (UN IGME). Levels and Trends in Child Mortality: Report 2017.

11. Bangladesh Bureau of. Statistics. Report on Bangladesh Sample Vital Statistics 2016. Reproduction, Documentation \& Publication Section (RDP), Bangladesh Bureau of Statistics (BBS), Dhaka; 2017.

12. Rahman H. Etiology and outcomes of acute kidney injury: A comprehensive study in four tertiary centers of Dhaka. J Ped Nephrol. 2017; 5: 1-5.

13. Ferdaus T, Afroz S, Hanif M, Mollah MAH, Banerjee M. Role of AKIN staging for diagnosis of neonatal acute kidney injury. Paed Neph J Bangladesh. 2017; 2: 14-18.

14. Ottonello G, Dessì A, Neroni P, Trudu ME, Manus D, Fanos V. Acute kidney injury in neonatal age. J Pediatr Neonat Individual Med. 2014; 3: e030246.

15. Afroz S, Ferdous T, Hanif M, Mollah MAH, Banerjee M, Khan TH. Etiology and outcome of neonatal acute kidney injury in a special care baby unit. Northern Intern Med Coll J. 2016; 7: 127-30.

16. Afroz S, Simi MA, Sharmin S, Khanum R. Aetiology and outcome of acute kidney failure in Bangladeshi children: Dhaka Medical College Hospital experience. J Dhaka Med Coll. 2015; 24: 86 $-91$.

17. Rahman S, Gupta RD, Islam N, Das A, Shaha AK, Khan MAI, Rahman MM. Pregnancy related acute renal failure in a tertiary care hospital in Bangladesh J Med. 2012; 13: 129-32.

18. Ahmed S, Chowdhury MN, Rahman M, Bhuiyan, Muqueet MA, Majumder MA. Study of acute renal failure in rhabdomyolysis. J Bangladesh Coll Phys Surg. 2006; 24: 93-96.

19. Subramanian S, Agarwal R, Deorari AK, Paul VK, 
Bagga A. Acute renal failure in neonates. Indian J Pediatr. 2008; 75: 385-91.

20. Ahsan HAMN, Ahmed S, Karim SR, Ahmed MN Acute renal failure following prolong exercise. Bangladesh Renal J. 1999; 18: 25-27.

21. Alam KS, Huda MN, Rashid HU, Saha M. Prevalence of diabetes mellitus, hypertension, proteinuria and association of these risk factors with estimated glomerular filtration rate (eGFR) in adult disadvantaged population. Bangladesh Renal J. 2010; 29: 1-6.

22. Faroque MO, Rashid HU, Rahman MH, Alam MR, Islam S. Prevalence of diabetes mellitus, hypertension and proteinuria in a rural area of Bangladesh. Bangladesh Renal J. 2010; 29: 7-11.

23. Hanif M, Mobarak MR, Ronan A. Fatal renal failure caused by diethylene glycol in paracetamol elixir: the Bangladesh epidemic. BMJ. 1995; 311: 88-91.

24. Askenazi DJ, Ambalavanan N, Goldstein SL. Acute kidney injury in critically ill newborns: What do we know? What do we need to learn? Pediatr Nephrol. 2009; 24: 265.

25. Cao Y, Yi ZW, Zhang H. Etiology and outcomes of acute kidney injuries in Chinese children: A prospective multicentre investigation. BMC Urol. 2013; 13: 41 .

26. Ghani AA, Al Helal B, Hussain N. Acute renal failure in pediatric patients: Etiology and predictors of outcome. Saudi J Kidney Dis Transpl. 2009; 20: 6976.

27. Mathur NB, Agarwal HS, Maria A. Acute renal failure in neonatal sepsis. Indian J Pediatr. 2006;73: 499-502.

28. Prins I, Plotz FB, Uiterwaal CS, van Vught HJ. Lowdose dopamine in neonatal and pediatric intensive care: A systematic review. Intensive Care Med. 2001; 27: 206-10.
29. Friedrich JO, Adhikari N, Herridge MS, Beyene J. Meta-analysis: Low-dose dopamine increases urine output but does not prevent renal dysfunction or death. Ann Intern Med. 2005; 142: 510-24.

30. Karthik S, Lisbon A. Low-dose dopamine in the intensive care unit. Semin Dial. 2006; 19: 465-71.

31. Barrington K, Brion LP. Dopamine versus no treatment to prevent renal dysfunction in indomethacin -treated preterm newborn infants. Cochrane Database Syst Rev. 2002.

32. Koralkar R, Ambalavanan N, Levitan EB, McGwin G, Goldstein S, Askenazi D. Acute kidney injury reduces survival in very low birth weight infants. Pediatr Res. 2011; 69: 354-58.

33. Bagga A, Bakkaloglu A, Devarajan P, Mehta RL, Kellum JA, Shah SV, Molitoris BA, Ronco C, Warnock DG, Joannidis M, Levin A. Acute kidney injury network. Improving outcomes from acute kidney injury: Report of an initiative. Pediatr Nephrol. 2007; 22: 1655-58.

34. Kellum JA. Kidney disease improving global outcome. KDIGO clinical practice guidelines for acute kidney injury. Kidney Int Suppl. 2012; 2: 1138.

35. Coca SG, Singanamala S, Parikh CR. Chronic kidney disease after acute kidney injury: A systematic review and meta-analysis. Kidney Int 2012; 81: 442-48.

36. Bruel A, Rozé JC, Flamant C, Simeoni U, RousseyKesler G, Allain-Launay E. Critical serum creatinine values in very preterm newborns. PLoS ONE. 2013; 8: e84892

37. Bouchard J, Soroko SB, Chertow GM. Program to Improve Care in Acute Renal Disease (PICARD) Study Group. Fluid accumulation, survival and recovery of kidney function in critically ill patients with acute kidney injury. Kidney Int. 2009; 76: 422 27. 